\title{
Corporate Fundamentals, BI Rate And Systematic Risk: Evidence From Indonesia Stock Exchange
}

\author{
Perdana Wahyu Santosa and Nita Puspitasari \\ Master of Management Program, Universitas YARSI \\ Email: perdana.wahyu@yarsi.ac.id
}

\begin{abstract}
The aim of this study is to understand the effect of company\&\#39;s fundamental factors and BI rate on systematic risk (beta) on the Indonesia Stock Exchange (IDX). The focus of this study is on systematic risk which was measured through beta $(\beta)$, where each stock had a different beta. The analyses used independent variables of sales growth, net profit margin, debt to equity ratio and BI rate on stock beta. The data used were quarterly data of issuers listed in the LQ-45 index in the period of 2009-2016 which were analysed using panel data method. The conclusion of analysis is that SG, NPM and DER contribute a significant impact on systematic risk, but the BI rate, does not offer significant influence on stock beta $(\beta)$. Implication: corporate fundamental factors such as sales growth, net profit margin and solvency has effect significantly on beta $(\beta)$, however BI rate does not.
\end{abstract}

Keywords: systematic risk, beta, sales growth, net profit margin, debt to equity ratio, BI rate

\section{INTRODUCTION}

Systematic risk or known as market risk of each company (issuer) is a type of risk that is undiversifiable or better known as stock beta ( $\beta$ ) (Bodie et al., 2014; Elton et al., 2013). It is named market risk because it relates to all changes that occur in the capital market as a whole and cannot be diversified through portfolio formation (Alena et al., 2017). Thus, the characteristics and uniqueness of a company have a significant effect on its stock beta'svalue (Husnan, 2015). Some of the characteristics of a company related to its systematic risk are the fundamental factors of corporate finance, trading activities and macroeconomics (Santosa and Laksana, 2011). Systematic risk is measured by the beta $(\beta)$ of a market, which is the beta of a security relative to its market risk, or measured by the stock sensitivity to a market (Bodie et al., 2014). Therefore, if a security has more than one $\beta$, then it is considered as a high-risk stock, because the systematic risk of the stock is higher than the systematic risk of the market, and vice versa (Santosa and Laksana, 2011).

The relationship between corporation's fundamental factors and the beta values of stocks listed in LQ45 often shows different fluctuations. If this empirical phenomenon is associated with previous studies, a gap will occur between the result of those studies and the existing empirical fact. In 2013,the salesgrowth variable of companies listed in the LQ45 index recorded an increase, but the stock beta $(\beta)$ variable actually declined (Rahmawati, 2010). This is contrary to the results of previous study which have shown that the sales growth variable affect the stock beta positively (Kumar et al., 2015). 
(Julduha and Kusumawardhani, 2013) have stated that the net profit margin variable has a negative effect on stock beta $(\beta)$, whereas the study conducted by (Nurdina, 2014) has shown that the net profit margin variable has a positive effect on stock beta. The difference in these conclusions makes the topic of this study interesting because there will be a deeper argument to find the cause.

(Kumar et al., 2015) find that the debt to equity ratio (DER) variable, according to the analysis, has a positive effect on stock beta. Another fact in 2010 , the debt to equity ratio was seen experiencing a decrease, while stock beta $(\beta)$ experienced an increase. This is in accordance with previous study that has stated that the debt to equity ratio variable negatively affects stock beta $(\beta)$. (Santosa and Laksana, 2011) has also stated that the relationship between DER and stock beta has the potential to be negative or positive depending on the level of leverage and the monetary condition of a nation.

The interest rate variable (BI Rate), according to the study done by (Suprio, 2004), has a positive effect on stock beta. (Alena et al., 2017) and (Sadeli, 2010) have also agreed that the influence of interest rate tends to be positive if macro economy experiences a meaningful shock. Empirically in 2014, it can be seen that BI rate experienced a decrease along with stock beta $(\beta)$, which also experienced a decrease. Hence, this fact is in accordance with the results of previous studies which have stated that the BI rate variable has a positive effect on stock beta $(\beta)$ (Chen, 2014).

Previous studies have examined a lot about the relationship between several components of financial variables and stock beta. But sometimes the result can be different or even contradictory between one study and another. Differences can be caused by many factors such as study periods, methods, analyses and others. Previous studies include the works of (Alena et al., 2017), (Amtiran et al., 2015), (Chen, 2014), (Nurdina, 2014), (Julduha and Kusumawardhani, 2013), (Prakoso, 2012), (Santosa and Laksana, 2011), (Sadeli, 2010), (Fidiana, 2010), (Rachmawati, 2010).

Because there is an inconsistency between empirical phenomenon and the theories and/or results of previous studies, there is a need for re-examination, so further study is necessary. This study was conducted to examine the influence of the fundamental factors of corporation (company) as well as macroeconomic factor (monetary) on systematic risk or stock beta $(\beta)$. The fundamental factors of corporation used in this study included 3 (three) main variables, namely revenue growth (sales growth), profitability (net profit margin), and leverage (debt to equity ratio). For macroeconomic variable, the benchmark interest rate was used, namely BI rate, based on the consideration of the close relationship between capital market performance and the monetary system (Chen, 2014; Nurdina, 2014).

\section{THEORITICAL REVIEW}

Market Risk. Stock Beta $(\beta)$ is a measure of risk derived from the relationship between the level of profit of a stock and the market. This risk comes from several fundamental factors of a company and market characteristic factors on the company's stocks. This beta $(\beta)$ is used to measure the market risk that cannot be eliminated by diversification (undiversifiable).

Stock Beta is a measure (volatility) of security return or portfolio return to market return (Kumar et al., 2015). Stock Beta ( $\beta$ ) can be measured by estimation 
analysis using historical data. Beta measured by historical data is then used to estimate future beta (Bodie et al., 2014). The beta can then be calculated using market data (security return and market return) with simple regression.

Stock Beta $(\beta)$ can be calculated using Single Index Model (SIM) regression. According to SIM, there are two important factors that are most influential on the return level of a stock, $R_{i}$ and market return, $R_{M}$ w hich is the percentage of changes in the stock index. The SIM formula is formulated as the following OLS regression:

$$
R_{i}=\alpha_{i}+\beta_{i} R_{M}+\varepsilon_{i}
$$

Description:

$\mathrm{R}_{\mathrm{i}} \quad: i^{\text {th }}$ security return.

$\alpha_{\mathrm{i}} \quad$ : expected value of security return that is independent towards market return.

$\beta_{\mathrm{i}} \quad$ : beta coefficient $(\beta)$ that measures $\mathrm{R}_{\mathrm{i}}$ due to changes in $\mathrm{R}_{\mathrm{m}}$.

$\mathrm{R}_{\mathrm{M}} \quad$ : market return level, which is also a random variable.

$\mathrm{e}_{\mathrm{i}} \quad$ : residual error, random variableE $\left(\mathrm{e}_{\mathrm{i}}=0\right)$.

If a stock with stock $\beta=1$ indicates that the condition is the same as the market, then a stock with $\beta<1$ shows less sensitive condition, changing based on market condition (low risk), while a stock with $\beta>1$ shows that stock prices are more sensitive (high risk) compared to the market index (Bodie et al., 2014).

This concept starts with lowering the covariance between excess return on a particular stock $(i)$, namely $R_{i}$, and market index $\left(R_{M}\right)$. According to the definition, a unique (special) part of a company called an unsystematic part has $\operatorname{Cov}\left(R_{M, e i}\right)=0$. Thus, the covariance of the excess return on stock- $i$ with its market index is formulated as follows:

$\operatorname{Cov}\left(R_{i}, R_{M}\right)=\operatorname{Cov}\left(\beta_{i} R_{M}+e_{i}, R_{M}\right)=\beta_{i} \operatorname{Cov}\left(R_{M}, R_{M}\right)+\operatorname{Cov}\left(e_{i}, R_{M}\right)=\beta_{i} \sigma^{2}{ }_{M}$

The constant $\alpha_{\mathrm{i}}$ can be excluded from the covariance component $\alpha_{\mathrm{i}}$ because it has zero covariance with all variables. Thus, $\operatorname{since} \operatorname{Cov}\left(R_{i}, R_{M}\right)=\beta_{i}{ }^{2}{ }_{M}$, then equation (1) namely the slope of regression as index model is equivalent to (Bodie et al., 2014):

$$
\beta_{i}=\operatorname{Cov}\left(R_{i}, R_{M}\right) / \sigma^{2}{ }_{M}
$$

The beta coefficientof index model changes to the same beta as the model coefficientof Capital Asset Pricing Model (CAPM) which is the expected return of $E\left(R_{i}\right)$.

Hypothesis Development. Sales Growth. In general, growth describes something positive because it shows company's ability to obtain certain values. According to (Brealey et al., 2016), growth rate is related to several financial aspects, such as sales, net profit, operating profit, dividends to earnings per share. (Meanwhile et al., 2013) have argued that the sales of a company describes a measure of an increase in assets, especially an increase in trade receivables and then into cash caused by the sales of products/services or finished goods inventory.

Therefore, growth can be seen from two sides, namely in terms of sales and assets, primarily the current assets, but it does not necessarily increase the net profit and cash flow significantly. (Rachmawati, 2011) has proved that the value of increased sales (ceteris paribus) causes the systematic risk of a stock to actually decrease or there is an inverse correlation. 
H1: Sales Growth affecting Systematic Risk $(\beta)$

Net Profit Margin. According to (Subrahmanyan, 2014), Net Profit Margin (NPM) is the ratio of net profitto sales; hence, the greater NPM is, the more productive company's profitability performance will be, which in turn will increase the confidence of investors to invest in the company. This ratio shows how much percentage of net profit earned from each sale. The greater this ratio, the better the profitability of the company to get high profit (Van Horne and Wachowicz, 2009).

Along with the increase in NPM, the earning per share will also increase, and therefore will build investors' confidence in the capital market through equity and debt. Increased EPS will surely trigger the stock price to increase, due to the expectation and promising future outlook of the company (Brealy et al., 2016. With the increase in stock price, price volatility (risk) will also increase due to overreaction factor and price reversal from the market; therefore, it will trigger an increase in the systematic risk of stock (Santosa, 2011).

H2: Net Profit Margin affectingSystematic Risk ( $\beta)$

Leverage (Debt to Equity Ratio). Higher leverage (debt to equity ratio) illustrates that the capital structure of a company is greater than the debt financed by equity. Theoretically, an increase in DER will raise the value of a company due to the impact of the tax shield (Brealy et al., 2016). (Amtiran et al., 2015) has argued that DER is positively correlated to company's size and profitability due to tax benefit, especially in banking sector. However, if solvency is excessive, it will trigger financial distress to company's finance. Thus, the optimal corporate leverage target must be set, because it determines the benefits and costs of debt, especially the emergence of agency costs from financial distress and tax shield from debt financing(Army, 2013; Amtiran et al., 2015).

The increase in DER will trigger the potential for financial distress; consequently, it will reduce company's ability to fulfil its obligations, both in short and long terms. Thus, the business risk and company's finance will increase and therefore affect its size and profitability, which affect investors' confidence, resulting in the increase of systematic risk. (Prakoso, 2012) and (Army, 2013) have discovered that an increase in company's DER will raise the systematic risk of its stocks, or in other words there is a positive relationship between DER and beta $(\beta)$.

$\mathrm{H}_{3}$ : Debt to Equity Ratio affecting Systematic Risk $(\beta)$

Benchmark Interest Rate (BI rate). (Alena et al., 2017) has found that the shock of the benchmark interest rate is responded positively by the stock beta of the sectoral index. Furthermore, it is explained that interest rate provides the highest contribution compared to other macroeconomic variables. In general, an increase in interest rate will have a negative impact on issuers in the capital market, especially those using excessive loan funds. Issuers' profit will be eroded by high interest expense, resulted in an increase of systematic risk (Elton, et al., 2013).

Another opinion from (Julduha and Kusumawardhani, 2013) states that the findings related to the influence of the benchmark interest rate on systematic risk are not significant. It is in contrast to the results of study conducted by (Chen, 2014) which have shown that the benchmark interest rate (BI rate) has a negative effect on stock beta. 
(Fitriawati, 2009) has stated that interest rate affects stock beta. This is because an investor in choosing an alternative investment will tend to choose a profitable investment. If the interest rate is higher than the stock return, investor tends to choose a risk-free investment such as deposits and bonds (low risk) than a stock investment with high risk, and vice versa.

H4: Benchmark Interest Rate affecting Systematic Risk $(\beta)$

\section{METHODOLOGY}

Populations and Samples. The populations in this study amounted to 45 companies whose stocks belong to the LQ 45 index listed on the IDX for the period of 20092016. The selection of these populations was targeted on liquid stocks. The liquidity of a stock can be known if it is always actively traded in the market. However, not all populations were subject to the study, so sampling was needed. The sample selection technique conducted in this study was purposive sampling, in which the samples were selected on the specific criteria adapted to the purpose of this study (Santosa and Hidayat, 2014).

Some criteria in the sampling were as follows: (1) The companies that were sampled were companies whose stocks were included in the LQ 45 index listed on the Indonesia Stock Exchange (IDX) during the period of 2009-2016. (2) The companies that were sampled had issued audited financial statements using IDR/USD currency during the period of 2009-2016. (3) The companies that were sampled were companies that had variables used in this study, namely sales growth, net profit margin, debt to equity ratio, and stock beta.

There were 21 companies whose stocks were always listed in LQ-45 during the period of 2009-2016 and there were 5 companies that did not use the Rupiah currency in their finance, so the samples obtained consisted of 16 companies.

Variable Operationalization. Variable operationalization used in this study included systematic risk proxy, growth, profitability, leverage and macroeconomics, namely:

Table 1. Study Variable Operationalization

\begin{tabular}{|c|c|c|c|c|}
\hline No & Variable & Definition & Indicator & Scale \\
\hline 1 & $\begin{array}{l}\text { Stock } \\
\text { Beta }\end{array}$ & $\begin{array}{l}\text { The measure of the } \\
\text { sensitivity of security- } \\
\text { ireturnto market return }\end{array}$ & $\beta_{i}=\frac{\operatorname{Cov}\left(R_{i}, R_{M}\right)}{\sigma_{M}^{2}}$ & Ratio \\
\hline 2 & $\begin{array}{l}\text { Sales } \\
\text { Growth }\end{array}$ & $\begin{array}{l}\text { Sales growth from one } \\
\text { periode to the next }\end{array}$ & Sales Growth $=\frac{\text { Sales }_{t}-\text { Sales }_{t-1}}{\text { Sales }_{t-1}}$ & Ratio \\
\hline 3 & $\begin{array}{l}\text { Net Profit } \\
\text { Margin }\end{array}$ & $\begin{array}{l}\text { The ratio of net profit } \\
\text { after tax to sales }\end{array}$ & $N P M=\frac{\text { Net Income }}{\text { Sales }}$ & Ratio \\
\hline 4 & $\begin{array}{l}\text { Debt to } \\
\text { Equity } \\
\text { Ratio }\end{array}$ & $\begin{array}{l}\text { The ratio to measure } \\
\text { funding from debt } \\
\text { versus equity }\end{array}$ & $D E R=\frac{\text { Debt }}{\text { Equity }}$ & Ratio \\
\hline
\end{tabular}




\begin{tabular}{llll}
\hline \hline BI Rate & $\begin{array}{l}\text { The benchmark } \\
\text { interest rate of } \\
\text { inflation, the rupiah } \\
\text { exchange rate and } \\
\text { banking. }\end{array}$ & $\begin{array}{l}\text { BI Rate }=\text { the benchmark interest } \\
\text { rate level stipulated by BI. }\end{array}$ & Ratio \\
\hline
\end{tabular}

Source: From various references (2018)

Analysis Model. The analysis model used for this study is in accordance with the previous hypothesis as follows:

$$
\operatorname{Beta}_{i t}=\alpha_{i t}+\beta_{1} S G_{i t}+\beta_{2} N P M_{i t}+\beta_{3} D E R_{i t}+\beta_{4} B I R_{i t}+\varepsilon_{i t} \ldots \ldots \ldots .
$$

Description:

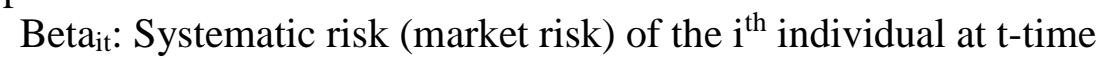

$\mathrm{SG}_{\mathrm{it}}$ : Sales growth-iat t-time

$\mathrm{NPM}_{\mathrm{it}}$ : Net profit margin-i at t-time

DER $_{\text {it }}$ : Debt to equity ratio-i at t-time

$\mathrm{BIR}_{\mathrm{it}}$ : $\mathrm{BI}$ rate (Benchmark Interest Rate $\mathrm{BI}$ ) at t-time

Panel Data Analysis. To get the result of the study in accordance with the aim of the study, it was necessary to do data analysis technique. The data used for the study were panel data of 16 companies listed on the Indonesian Stock Exchange (IDX) in the period of 8 years (2009-2016). According to (Nachrowi, 2006), panel data is the data collected cross-sectionally and within a certain time period (time series). Crosssection data is the data collected of many individuals in one period. Time series data is the data collected of an individual from one period to another. Panel data analysis technique used to determine the effect of sales growth, net profit margin, debt to equity ratio, and BI rate variables on systematic risk $(\beta)$ was panel data estimation with econometric analysis model.

There are two stages in choosing an estimation method in the panel data. The first step is to compare least square pooling method using OLS or called the Common Effect Method (CEM) with the fixed effect method (FEM) using the Chowtest or Likelihood ratio test. If the test result show that the OLS model is the best, then this OLS or CEM model will be compared with the Random Effect model using the Lagrange Multiplier (LM) test. But if the fixed effect model (FEM) is better than CEM, then it will be compared with the random effect method using the Hausman-test to determine which regression model will be used as the best model (Gujarati and Porter, 2009).

According to (Gujarati and Porter, 2009), there are three methods of analysis in panel data, namely:

Pooled Least Square (Common Effect Model); basically this PLS (CEM) panel data model combines cross-section data with time series data. The analysis used is a multivariable OLS regression. This method uses simpler regression analysis than the next two models. The weakness of this model is that there is less visible difference between individuals and differences between times due to the intercept and slope of the same model. The PLS (CEM) model is as follows:

$$
Y_{i t}=\alpha_{0}+\beta_{1} X_{1 i t}+\beta_{2} X_{2 i t}+\beta_{3} X_{3 i t}+\ldots+\beta_{n} X_{n i t}+\varepsilon_{i t}
$$


Description: $Y_{\mathrm{it}: d e p e n d e n t}$ variable of individual-i andt-time; $\mathrm{X}_{\mathrm{it}}$ : independent variable ofindividual-i andt-time; $\alpha$ : intercept; $\beta$ : independent variable coefficient; $\varepsilon_{\mathrm{i}}$ : residual (surprises) ofindividual-i andt-time.

Fixed Effect Model (FEM); This FEM model assumes the difference between intercepts using dummy variable technique that can be formulated as follows:

$$
Y_{i t}=\sum_{\mathrm{i}=1}^{\mathrm{n}} \alpha_{\mathrm{i}} D_{i}+\beta_{1} X_{1 i t}+\beta_{2} X_{2 i t}+\ldots+\beta_{n} X_{n i t}+\varepsilon_{i t}
$$

Description: $Y_{\mathrm{it}}$ dependent variableindividual-i andt-time; $\mathrm{X}_{\mathrm{it}}$ : independent variableindividual- $\mathrm{i}$ andt-time; $\alpha$ : intercept; Di: dummy variable; $\beta$ : independent variable coefficient; $\varepsilon_{\mathrm{i}}$ : residual (surprises) of individual-i andt-time.

Random Effect Model (REM); The REM model uses a different approach from the two previous models, namely using error terms variable. This error terms or disturbance variable allows the connection between individual-i and between t-time. This REM model writing can be described as follows:

$$
Y_{i t}=\alpha_{0}+\beta_{1} X_{1 i t}+\beta_{2} X_{2 i t}+\beta_{3} X_{3 i t}+\ldots+\beta_{n} X_{n i t}+\varepsilon_{i t}+\mu_{i t}
$$

Description: $Y_{\mathrm{it}}$ dependent variableindividual-i andt-time; $\mathrm{X}_{\mathrm{it}}$ : independent variableindividual- $\mathrm{i}$ andt-time; $\alpha$ : intercept; Di: dummy variable; $\beta$ : independent variable coefficient; $\varepsilon_{\mathrm{i}}$ : residual (surprises) of individual-i andt-time; $\mu_{\mathrm{i}}$ : random error terms.

\section{RESULTS AND DISCUSSION}

Data Descriptive Analysis. Descriptive statistics were used to see an overview of the data used. Based on the data of the study obtained from the Indonesian Capital Market Directory (ICMD) and IDX company report on companies whose stocks were registered in LQ45 members on the IDX during the period of 2009-2016, the descriptive statistics table of systematic risk (beta) table, sales growth, net profit margin (NPM), debt to equity ratio (DER), and BI rate variables is as follows:

Table 2. Data Descriptive Analysis Results

\begin{tabular}{lccccc}
\hline & BETA & SG & NPM & DER & BIRATE \\
\hline Mean & 0.798250 & 0.169432 & 0.262927 & 2.986338 & 0.062534 \\
Maximum & 4.97674 & 0.96934 & 0.48114 & 12.14192 & 0.084531 \\
Minimum & -2.882992 & -0.38065 & 0.05915 & 0.13875 & 0.007840 \\
Std. Deviation & 1.724089 & 0.184752 & 0.098582 & 3.63229 & 0.017666 \\
\hline
\end{tabular}

Source: Output Eviews 9 Processed Researcher

\section{Panel Data Analysis Model Estimation Results}

Common Effect Model. First, data processing was done using the Common Effect Model (CEM) approach as one of the requirements for conducting the Chow/likelihood ratio test. The result of data processing is shown in Table 3. 
Santosa and Puspitasari: Corporate Fundamentals, BI Rate and Systematic Risk....

Table 3. Common Effect Method Estimation Result

\begin{tabular}{lcccc}
\hline \multicolumn{1}{c}{ Variable } & $\begin{array}{c}\text { Regression } \\
\text { Coefficient }\end{array}$ & Standard Error & t-Statistics & Probability \\
\hline SG & -3.350365 & 0,153648 & -22.84684 & 0.0000 \\
NPM & 6.505283 & 1.230079 & 4.963326 & 0.0000 \\
DER & -0.132532 & 0.033494 & -3.956828 & 0.0001 \\
BIRATE & -5.538987 & 7.652512 & -0.774411 & 0.4392 \\
Coefficient & 0.563186 & 0.554255 & 1.016102 & 0.3102 \\
\hline $\mathrm{R}^{2}$ & $: 0,602938$ & & & \\
Adjusted R & $: 0,598747$ & & & \\
Prob (F-Statistic) & $: 0,000000$ & & & \\
\hline Sourc: Output Eviews & 9 Processed & &
\end{tabular}

Source: Output Eviews 9 Processed Researcher

From Table 3, it can be seen that by using CEM we have obtained a determinant coefficient $\mathrm{R}^{2}$ at $60.3 \%$ andthere are 3 (three) independent variables that are statistically significant at $\alpha=5$, namely sales growth, net profit margin, and debt to equity ratio. Meanwhile, the interest rate variable has no significant effect on stock beta.

Fixed Effect Model. After that, the processing of the data using the Fixed Effect Model (FEM) approach to be compared with the CEM approach method in the Chow-test was conducted. The result of the data processing is shown in Table 4 as follows:

Table 4. Fixed Effect Model Method Estimation Result

\begin{tabular}{lcccc}
\hline \multicolumn{1}{c}{ Variable } & $\begin{array}{c}\text { Regression } \\
\text { Coefficient }\end{array}$ & Standard Error & t-Statistics & Probability \\
\hline SG & -3.553087 & 0.158691 & -22.38991 & 0,0000 \\
NPM & 9.003820 & 2.472296 & 3.641886 & 0,0003 \\
DER & $-0,012264$ & 0.153433 & -0.079930 & 0.9363 \\
BIRATE & -4.268242 & 7.193873 & -0.593316 & 0.5533 \\
Coefficient & -0.492263 & 1.030470 & -0.477707 & 0.6331 \\
\hline R2 & $: 0,620301$ & & & \\
Adjusted R2 & $: 0,600482$ & & & \\
Prob (F-Statistic) & $: 0,000000$ & & & \\
\hline
\end{tabular}

Source: Output Eviews 9 Processed Researcher

From Table 4, it can be seen that by using FEM we have obtainedR ${ }^{2}$ at $62 \%$ which is greater than the ${ }^{2}$ of CEM. However, FEM method shows only two independent variables that are statistically significant at $\alpha=5 \%$, namely the sales growth and net profit margin (NPM) variables.

Chow Test. To select the best panel data model estimation between CEM and FEM, Chow or likelihood ratio test was done. The hypotheses used were:

$\mathrm{H}_{0}$ :the regression model follows the Common Effect Model

$\mathrm{H}_{\mathrm{a}}$ :the regression model follows the Fixed Effect Model

The basic of decision making: 
If the probability of a Chi-square value $>0.05$, then $\mathrm{H}_{0}$ is accepted.

If the probability of the Chi-square value $<0.05$ then $\mathrm{H}_{0}$ is rejected.

Table 5. Chow-Test Result

\begin{tabular}{lrrr}
\hline $\begin{array}{l}\text { Redundant Fixed Effects Tests } \\
\text { Pool: PWSNITA } \\
\text { Test cross-section fixed effects }\end{array}$ & & & \\
\hline Effects Test & Statistics & d.f. & Prob. \\
\hline Cross-section F & 1,109708 & $(15,364)$ & 0.3455 \\
Cross-section Chi-square & 17,170536 & 15 & 0.3088 \\
\hline
\end{tabular}

Source: Output Eviews 9 Processed Researcher

From the result of the Chow-test in Table 5, it is noted that the probability value of the Chi-square value is 0.3088 . Because the probability value of the Chi-square value is greater than $0.05, \mathrm{H}$ is then accepted. So, it can be concluded that based on the result of the Chow-test, the best panel data estimation model in this study is the Common Effect Model approach.

Random Effect Model. Since the result of the Chow-test had declared the CEM method to be the best, then data processing was carried out using the Random Effect Model (REM) approach that wouldbe compared with CEM. The processing of the REM approach method was done to compare it with the CEM method through the Lagrange Multiplier (LM) test. The result of data processing is seen in Table 6 of Random Effect Model (REM) approach method as follows:

Table 6. Random Effect Model Method Estimation Result

\begin{tabular}{lcccc}
\hline \multicolumn{1}{c}{ Variable } & $\begin{array}{l}\text { Regression } \\
\text { Coefficient }\end{array}$ & StandardError & t-statistics & Probability \\
\hline SG & & & -2.788452 & 0.0000 \\
NPM & -3.515484 & 0.154266 & & \\
DER & 6.268012 & 1.309784 & 4.785530 & 0.0000 \\
BIRATE & -0.134101 & 0.036898 & -3.634369 & 0.0003 \\
Coefficient & -5.410915 & 7.143505 & -0.757459 & 0.4492 \\
\hline $\mathrm{R}^{2}$ & 0.523950 & 0.568084 & 0.922369 & 0.3569 \\
Adjust R & $: 0.600770$ & & & \\
Prob(F Statistics) & $: 0.596556$ & & & \\
\hline SOl.000000 & & & & \\
\hline
\end{tabular}

Source: Output Eviews 9 Processed Researcher

From Table 6, it can be seen that by using REM we have obtained $\mathrm{R}^{2}$ which is approximately the same compared to $\mathrm{R}^{2}$ of CEM method, which is $60.07 \%$. The REM model shows 3 (three) independent variables, namely Sales growth (SG), Net Profit Margin (NPM), and Debt to Equity Ratio (DER), which are statistically significant at $\alpha=5 \%$. 
Lagrange Multiplier (LM) Test. Because Chow-Test had shown theCommon Effect Model (CEM) as the best panel data estimation model, then the next step was to compare it with the Random Effect Model (REM) method by using Lagrange Multiplier (Gujarati and Porter, 2009). The hypotheses used in this test were:

$\mathrm{H}_{0}$ :the regression model follows the Common Effect Model

$\mathrm{H}_{\mathrm{a}}:$ the regression model follows the Random Effect Modell

The basic of decision making:

If the probability of Breusch-Pagan value is $>0.05$, thenHo is accepted.

If the probability of Breusch-Pagan value is $<0.05$, then Ho is rejected.

Table7. Lagrange Multiplier(LM) Test

\begin{tabular}{|c|c|c|c|}
\hline \multicolumn{4}{|c|}{$\begin{array}{l}\text { Lagrange Multiplier Test for Random Effect } \\
\text { Null hypotheses: No effects } \\
\text { Alternative hypotheses: Two-sided (Breush-Pagan) and one sided }\end{array}$} \\
\hline & \multicolumn{3}{|c|}{ Test Hypotheses } \\
\hline & Cross-section & Time & Both \\
\hline Breush-Pagan & $\begin{array}{c}0.013731 \\
(\mathbf{0 . 9 0 6 7 )}\end{array}$ & $\begin{array}{c}0.729362 \\
(0.3931)\end{array}$ & $\begin{array}{c}0.743094 \\
(0.3887)\end{array}$ \\
\hline Honda & $\begin{array}{r}-1.17181 \\
(0.5466)\end{array}$ & $\begin{array}{r}-8.54027 \\
(0.8035)\end{array}$ & $\begin{array}{l}-686748 \\
(0.7349)\end{array}$ \\
\hline King-Wu & $\begin{array}{l}-1.17181 \\
(0.5466)\end{array}$ & $\begin{array}{r}-8.54027 \\
(0.8035)\end{array}$ & $\begin{array}{l}-627734 \\
(0.7349)\end{array}$ \\
\hline Standardized Honda & $\begin{array}{r}0.336147 \\
(0.3684)\end{array}$ & $\begin{array}{r}-6.09933 \\
(0.7290)\end{array}$ & $\begin{array}{c}-5186136 \\
(10.000)\end{array}$ \\
\hline Standardized King-Wu & $\begin{array}{r}0.336147 \\
(0.3684)\end{array}$ & $\begin{array}{r}-6.09933 \\
(0.7290) \\
\end{array}$ & $\begin{array}{c}-5.053056 \\
(10.000)\end{array}$ \\
\hline
\end{tabular}

Source: Output Eviews 9 Processed Researcher

From the result of the Lagrange Multiplier test, it is noted that the probability value of the Breusch-Pagan value is at 0.9067. Because the probability value of the BreuschPagan value is greater than $0.05, \mathrm{H}_{0}$ is then accepted; so, it can be concluded that based on the result of the Lagrange Multiplier test, the best panel data estimation model in this study is the Common Effect Model approach method. In the analysis, the Hausman test was no longer needed because it was proven that CEM is always the best model in comparison with FEM and REM.

In this study, four hypotheses were proposed regarding the effect of Sales Growth, Net Profit Margin, Debt to Equity Ratio, and BI Rate. Below will present the discussion on those four hypotheses with the discussion concept based on previous theories and studies. 


\section{DISCUSSION}

The Effect ofSales Growth onStock Beta. The result of the analysis states that the effect of the sales growth variable on stock beta is negative and significant. In other words, if a company's sales growth increases, stock beta $(\beta)$ will decrease. This estimation result is in accordance with the hypothesis that has been formulated earlier. In general, investors are less confident in sales growth (revenue) because many company managers misuse accounting policies for earnings management (window dressing) of the financial statement. Earnings management is usually started with a "revenue account" so as to reduce the economic value of the financial statement (Subrahmanyan, 2014). This causes fewer and fewer investors to believe in revenue. In addition, increasing sales is not a guarantee to the increase of company's net profit and cash flow.

Theresults of this study support the result of studies conducted by (Rachmawati, 2010) and (Santosa and Laksana, 2011) that have previously stated that the sales growth variable has a negative effect on stock beta. But it is contrary to the study conducted by (Indriastuti, 2001) which has argued that the sales growth variable has a positive effect on beta.

The Effect ofNet Profit Margin onStock Beta. The second hypothesis states that the Net Profit Margin variable has a positive effect on stock beta. The result of the CEM panel data regression shows that the net profit margin variable has a significant and positive effect on stock beta. Thus, any increase in NPM will increase the value of the systematic risk of a stock.

NPM is the ratio of net profit to sales. In theory, higher NPM indicates that company's ability to generate profit increases, so there is a possibility that the dividend distributed to shareholders will increase and EPS will also increase. The increase in dividend and EPS will trigger investors' interest in the capital market, hence prices will increase and there will be excessive fluctuation. The excess stock price fluctuation is generally above the market index fluctuation, therefore stock beta continues to rise above one (Amtiran et al., 2015). The results of this study support the result of studies conducted by (Susilawati, 2001) and (Julduha and Kusumawardhani, 2013) which have shown that the net profit margin variable has a positive effect on beta.

The Effect ofDebt to Equity Ratio onStock Beta. The third hypothesis states that the Debt to Equity Ratio variable has a positive effect on stock beta. The result of panel data regression in Table 3 shows that the probability value ( $p$-value) of the debt to equity ratio variable is 0.0001 , where the number is smaller than the significance level of $5 \%$. This indicates that the debt to equity ratio variable has a significant effect on stock beta. The direction of the relationship between debt to equity ratio variable and stock beta is negative, or in other words, if the debt to equity ratio of a company increases, the stock beta is low.

A high DER level shows a greater composition of total debt (long term and short term) compared to its equity. So, it will cause an increase in company's expense in fulfilling its debt obligation, including interest cost that arises in accordance with the level of company's debt. An increase in company's expense will automatically reduce the 
profit received by the company, because some of the revenue must be used to pay debts and interest costs (Brealey et al., 2006; Van Horne and Wachowicz, 2009).

With the decline in company's profit, it will certainly result in the decrease in the amount of dividend distributed to investors and the risk borne by investors will also decrease. The results of this study support the result of study conducted by (Amtiran et al., 2015) which has shown that the debt to equity ratio variable has a negative effect on stock beta $(\beta)$.

The Effect of BI Rate onStock Beta. The fourth hypothesis states that the BI Rate variable has a positive effect on stock beta $(\beta)$. The result of panel data regression in Table 3 shows that the probability value (p-value) of the BI Rate variable is 0.325 , where the number is greater than the significance level of $5 \%$. This indicates that the BI Rate variable does not significantly influence stock beta. This finding is not in accordance with the $\mathrm{H} 4$ hypothesis.

Based on the study conducted by (Chen, 2014), it is known that the changes in macroeconomic factors have a significant influence on systematic risk or market risk. If shock on the benchmark interest rate occurs, then the correlation with stock beta is proved to be significant and positive. Even interest rate in crisis condition has the greatest influence on systematic risk (Alena et al., 2017). An increase in interest rate in large numbers will have a bad influence on stock issuers, especially if the debt financing is excessive, because it will increase the interest rate's expense, which will erode profit. This condition of excessive leverage will lead company to experience financial distress and even bankruptcy (Brealey et al., 2006; Subrahmanyam and Wild, 2010). This condition will make investors avoid high leverage stocks because of concerns about the shock of the benchmark interest rate.

\section{CONCLUSION}

The results of the study show that most of the variables used have a significant effect on systematic risk (stock beta). However, macroeconomic variable that uses benchmark interest rate (BI rate) has no significant effect on stock beta $(\beta)$. Some of the results of this study support previous studies, but there are also some that differ both in terms of coefficient and significance. This can happen because the methods and analyses used are different. But most of them complement previous findings.

Sales growth has a significant and negative effect, which means that every increase in sales growth will result in a decrease in the value of stock beta $(\beta)$. This is because sales growth will not necessarily increase company's profit or liquidity because of the possibility of earnings management practice that is commonly carried out management for their interest. In addition, an increase in company's revenue does not necessarily affect dividend value, so investors focus more on net profit and EPS. On the contrary, it was found that profitability with NPM proxy gives positive and significant result on this systematic risk. This reinforces the argument that investors are more concerned with the "bottom line", so an increase in profit will make stocks more attractive which can increase their stock beta.

The result of the discussion related to the effect of leverage on stock beta $(\beta)$ with DER proxy indicates that DER has a negative and significant effect; in other words, 
any increase in DER will decrease the stock beta. This is supported by several previous findings, because the higher the DER is, the higher the interest expense will be, resulting in the decrease of company's profit. In fact, if DER is too high, it has the potential to cause financial distress and reduce company' solvency. So, on this consideration, investors tend to avoid stocks with high DER and therefore the beta value decreases. Meanwhile, the test of macroeconomic influence with the benchmark interest rate (BI rate) proxy, which was hypothesized to have a significant influence, did not occur.

\section{REFERENCES}

Alena, E., Achsani, N.A, Andati, T. (2017). Dampak Guncangan Variabel Makroekonomi, terhadap Beta Indeks Sektoral di BEI. Jurnal Aplikasi Bisnis dan Manajemen, 3(3): 384-397.

Amtiran P.Y, Indiatuti, R. Masyita D. (2015) Determinants of systematic risk of banking sector in Indonesia Stock Exchange, Global Journal Business and Social Science Review, 4(1): 26-33.

Army, Juwita. (2013) Pengaruh Leverage, Likuiditas, dan Profitabilitas terhadap Risiko Sistematis Pada Perusahaan Perbankan yang Terdaftar di BEI Tahun 2009-2011, Jurnal Akuntansi, 1(2): 1-28.

Bodie, Z., Kane, A., Marcus, A.J. (2014). Investments, 10th Edition, New York: McGrawHill.

Brealey, R.A, Myers, S.C, Allen, F. (2011). Principle of Corporate Finance, Global Edition, New York: McGraw- Hill Irwin.

Chen, M. (2014). Analisis Pengaruh Perekonomian Makro dan Mikro yang Berpengaruh pada Risiko Sistematis Saham, Jurnal Nominal, 3(2): 75-100.

Chung-ki min (2014). Applied Econometrics: A Practical Guide, London, UK: Routledge Publisher.

Dwiarti, Rina. (2009). Analisa Faktor-Faktor Keuangan terhadap Risiko Sistematis di BEJ, Jurnal Ekobis 10(2): 354-364.

Elton, E.J, Gruber, M. J, Brown, S. J, and Goetzmann, W. N (2013). Modern Portfolio Theory and Investment Analysis, 9th Edition, Ney York: Willey

Fidiana. (2010). Pengaruh tingkat suku bunga, tingkat inflasi dan rasio keuangan terhadap beta saham, Jurnal Investasi, 6(1): 31-46.

Fitriawati. (2009). Pengaruh Uang Yang Beredar (M2), Kurs. Inflasi, Dan Tingkat Suku Bunga SBI Terhadap Beta Saham Syariah (JII) Dan Indeks Harga Saham Gabungan (IHSG). Jakarta: Thesis Universitas Islam Negeri Syarif Hidayatullah.

Greene, William, H. (2016). Applied Econometrics: Critical Concept in Economics, Londong UK: Routledge Publisher.

Husnan, Suad. (2015). Dasar-Dasar Teori Portofolio dan Analisis Sekuritas, Edisi Kelima, Yogyakarta: BPEE.

Julduha, N. dan Kusumawardhani, I. (2013). Pengaruh Net Profit Margin, Current Ratio, Debt to Asset Ratio, dan Tingkat Suku Bunga Terhadap Beta Saham Pada Perusahaan yang Terdaftar di JII", Jurnal Buletin Studi Ekonomi, 18(2).

Kumar, V., Aleemi, A. R., Ali, Akhtiar. (2015). The Determinants of Systematic Risk: Empirical Evidence From Pakistan's Banking Sector, Global Management Journal for Academic and Corporate Studies, 5(1): 146-154 
Nachrowi, D. (2006). Pendekatan Populer dan Praktis Ekonometrika Untuk Analisis Ekonomi dan Keuangan, Cetakan Pertama, Jakarta: Lembaga Penerbit FE UI.

Nurdina, I. (2014). "Pengaruh Faktor Fundamental Terhadap Beta Saham LQ45 periode 2006-2014". Skripsi: Universitas Diponegoro.

Prakoso, Agung B. (2012). “Analisis Faktor-Faktor yang Berpengaruh Terhadap Beta Saham Perusahaan (Studi Empiris Pada Perusahaan yang Tercatat Dalam Indeks Kompas 100 di Bursa Efek Indonesia 2007-2010)". Skripsi. Universitas Diponegoro.

Rachmawati, Sisca. (2011). "Analisis Pengaruh Faktor Fundamental Terhadap Risiko Sistematis (Beta) Pada Saham LQ45 yang Terdaftar di BEI Periode 2006-2008", Jurnal Ekonomi, Universitas Diponegoro.

Sadeli. (2010). "Analisis pengaruh variabel fundamental mikro-makro terhadap risiko saham, Jurnal Administrasi Bisnis, 6(2): 1-15.

Santosa, Perdana Wahyu. (2011). "Probability of Price Reversal and Intraday Trading Activity on Tick Size-25 at Indonesia Stock Exchange”, Jurnal Manajemen Teknologi, 10(3): 226-242.

Santosa.PerdanaWahyu, Laksana, Harry Yusuf. (2011). "Value at Risk, Market Risk and Trading Activity: CAPM Alternative Model", Journal of Applied Finance and Banking, 1(4): 239-268.

Santosa, PerdanaW., Hidayat, Ayat (2014). Riset Terapan: Teori dan Aplikasi, Edisi Pertama, Jakarta: Globalstat Press.

Subrahmanyam, K.R. (2014). Financial Statement Analysis, Ed. $11^{\text {th }}$, New York: McGraw Hill.

Van Horne, James., Wachowicz, John (2013). Fundamental of Financial Management, Ed. 13th, UK: Pearson Education Limited. 